\title{
The Hyalinizing Trabecular Tumor of the Thyroid Gland-Case Report: Morphologic, Cytological and Immunohistochemical Features
}

\section{Tiroidin Hyalinize Trabeküler Tümörü-Olgu Sunumu: Sitolojik, Morfolojik ve İmmünohistokimyasal Özellikleri}

\author{
Ebru Demiralay $^{1}$, Şemsi Altaner ${ }^{2}$, Hüseyin Yüce Bircan ${ }^{1}$, Banu Bilezikçi ${ }^{1}$ \\ ${ }^{1}$ Başkent Üniversitesi, Patoloji, Ankara, Türkiye \\ ${ }^{2}$ Trakya Üniversitesi, Patoloji, Edirne, Türkiye
}

DOI: $10.5505 /$ aot.2011.32042

\begin{abstract}
ÖZET
Hyalinize trabeküler adenom tiroidin az görülen benign bir neoplazmdır. Sitolojik yaymalarda ve parafin kesitlerde papiller ve medüller tiroid karsinomu ile karışabilir. Klinik olarak ötiroid olan 60 yaşında kadın hastada radyoaktif iyot ile sağ lobda soliter soğuk nodül tespit edildi. Tiroid ince iğne aspirasyon biyopsisi sitolojik olarak hiposellüler olup hücresel olarak papiller karsinom özellikleri gösteren hücreler içermekteydi. "Papiller karsinom şüphesi”" şeklinde rapor edildi. Hastaya să̆ subtotal tiroidektomi uygulanarak intraoperatif inceleme istendi. Makroskopik olarak iyi sınırlı, $2 \mathrm{~cm}$ çapta, çevresinde ince fibröz kapsülü bulunan kirli beyaz renkli nodül yapısı izlendi. Frozen kesitlerde hyalinize stromada solid adalar ve trabeküller patern gösteren nükleer psödoinklüzyonlar içeren hücreler ve mikrokalsifikasyonlar görülmesi üzerine papiller karsinom ile uyumlu olabileceği düşünüldü. Parafin kesitlerde tümör ince fibröz kapsül ve hyalinize stromaya sahip trabeküler yapılar oluşturmuş papiller karsinomun hücresel özelliklerine benzer hücrelerden oluşmaktaydı. İmmünohistokimyasal incelemede tümör hücreleri tiroglobulin pozitifti. HBME, CK19 ve kalsitonin negatifti. Olgu "Hyalinize trabeküler adenom" olarak rapor edildi. Nadir görülen bu tümörün sitolojik, morfolojik ve immünohistokimyasal özelliklerine dikkat çekmek amacıyla sunulmuştur.
\end{abstract}

Anahtar Kelimeler: Tiroid; Hyalinize trabeküler adenom; Sitoloji; İmmünohistokimya.

\begin{abstract}
Hyalinizing trabecular adenoma is a rare benign neoplasmof the thyroid gland. This can be confused with papillary carcinoma and thyroid medullary carcinoma in cytology from the permanent sections. Solitary "cold" nodule was detected in right thyroid lobewith radioactive iodine scanning of 60 years old clinically euthyroid female patient. The hypocellular thyroid fine needle aspiration consisted of cells that shows the features of papillary thyroid carcinoma. A final diagnosis was reported as a suspicious thyroid papillary carcinoma. A subtotal thyroidectomy was performed and intraoperative frozen sections were requested. Well-circumscribed, 2 $\mathrm{cm}$. in diameter, off-white colored nodules with a thin fibrous capsule surrounding structures were observed in macroscobic evaluation.In the frozen section analysis, It was thought to be compatible with papillary carcinoma due to having solid and trabecular patterns in the hyalinizing stroma, nucleer pseudoinclusions and microcalsifications. Tumors consisted of cells similar to cellular properties of papillary carcinoma are formed a thin fibrous capsule and trabecular structures with hyalinized stroma with in permanent sections. Tumor cells were stained diffusely positive for thyroglobulin, but negative staining with antibodies to HBME-1, CK19 and calcitonin. The case was reported as"hyalinizing trabecular adenoma". This rare tumor is presented to draw attention to the features of cytology, morphologic and immunohistochemical.
\end{abstract}

Key Words: Thyroid; Hyalinizing trabecular adenoma; Cytological; Immunohistochemistry.

\section{Giriş}

Hyalinize trabeküler adenom (HTA) ilk olarak 1987 y1lında Carney ve ark. tarafindan (1) poligonal, oval iğsi hücrelerden oluşan ve trabeküler yap1 yapan, hyalinize stromaya sahip lezyon olarak tanımlanmıştır. HTA'da en önemli nokta bu tümörün hem histolojik hem de sitolojik olarak papiller ve medüller karsinomla karışmasıdır (2-4). HTA başlangiçta benign olarak kabul edilmekle birlikte malign hyalinize trabeküler adenom da tanımlanmıştır. $\mathrm{Bu}$ nedenle son zamanlarda hyalinize trabeküler tümör tanıs1 kullanılmaktadır $(2,5)$. Sitolojik incelemelerde sıklıkla papiller ve medüller karsinomla 
karışmaktadır. HTA'nın sitolojisi genellikle sellüler olup kolloidden fakirdir. Tümör hücreleri genellikle gevşek veya küçük tek tabakalı gruplar yapar. Hücre nukleusları yuvarlak-oval şekilli ve ince kromatinlidir. İntranükleer psödoinklüzyonlar ve longitudinal yarıklanmalar sıklıkla görülür (4).

Tiroidin az görülen ve genellikle benign seyirli ancak tiroidin malign tümörleri ile karışan HTA sitolojik, morfolojik ve immünhistokimyasal (İHK) özellikleri ile bu makalede tartışılmıştır.

\section{Olgu Sunumu}

Altmışbeş yaşındaki kadın hasta 20 yıldır mutinodüler guatr nedeniyle levotiroksin sodyum kullanmaktaydi. Tiroid sintigrafisinde sağ lobda $16 \times 13 \mathrm{~mm}$ boyutlarda periferik hipoekoik halosu belirgin hafif hipoekoik, yer yer punktat kalsifikasyon içeren, doplerde ise aşırı vaskülaritesi bulunan nodül izlendi. Biyokimyasal olarak T3, T4 ve TSH normal sinırlardaydı. Nodülden tiroid ince iğne aspirasyon biopsisi (Tİ̈AB) yapıldı. Materyaller hücreden zengindi ve kolloidden fakir zeminde gevşek gruplar oluşturmuş yaygın intranükleer inklüzyonlar seçilen tirositler izlendi (Resim 1). Bu bulgularla "papiller karsinom şüphesi" olarak rapor edildi. Bunu takiben hastaya frozen eşliğinde tiroidektomi uyguland.

İntraoperatif inceleme için gönderilen sağ tiroid lobunda $2 \mathrm{~cm}$ çapında kirli beyaz renkli, düzgün sınırlı, kolloidden fakir bir adet nodül izlendi. $\mathrm{Bu}$ nodülden alınan frozen kesitlerinde hyalinize stromada trabeküler yapılar oluşturmuş, ve nükleer psödoinklüzyonlar içeren hafif pleomorfik hücreler ve mikrokalsifikasyonlar görüldü ve bu histolojik özellikleri sebebiyle "papiller karsinom kuşkulu lezyon" olarak genel cerrahi bölümüne bildirildi (Resim 2). Total tiroidektomi yapılarak operasyon sonlandirıldı. Rutin doku takibinden sonra uygulanan parafin kesitlerin 1 ş1k mikrokopik incelemesinde tümör düzgün sınırlıydı ve ince fibröz kapsülle normal tiroid dokusundan ayrilmaktayd. Tümör hücreleri belirgin trabeküler dizilim gösteren oval-iğsi geniş sitoplazmalı hücrelerden oluşmaktaydı. Nükleus membranı kalındı ve psödoinklüzyon ve yarıklanmalar göstermesi dikkat çekiciydi (Resim 3). Tümör hücreleri arasında PAS pozitif diastaz negatif hyalinize materyal mevcuttu. Tümör içinde belirgin kolloid, papiller oluşum ve kapsül ve vasküler invazyon görülmedi. Kristal viyole ile yapılan boyamalarda amiloidin negatif olduğu gözlendi.

Parafin bloklara uygulanan İHK incelemede tümör hücreleri tiroglobulin ile pozitifti. CK19, HBME-1 ve kalsitonin negatifti. MIB-1 hücre membranlarında lineer boyanma gösterdi ancak nükleer boyanması $\% 1$ 'den azd1. Morfolojik ve İHK bulguları ile olguya hyalinize trabeküler tümör tanısı kondu. Olgumuz düzgün bir kapsüle sahip olduğu, kapsül invazyonu yapmadığı, lenfatik ve venöz invazyon olmadığ olarak yorumland.
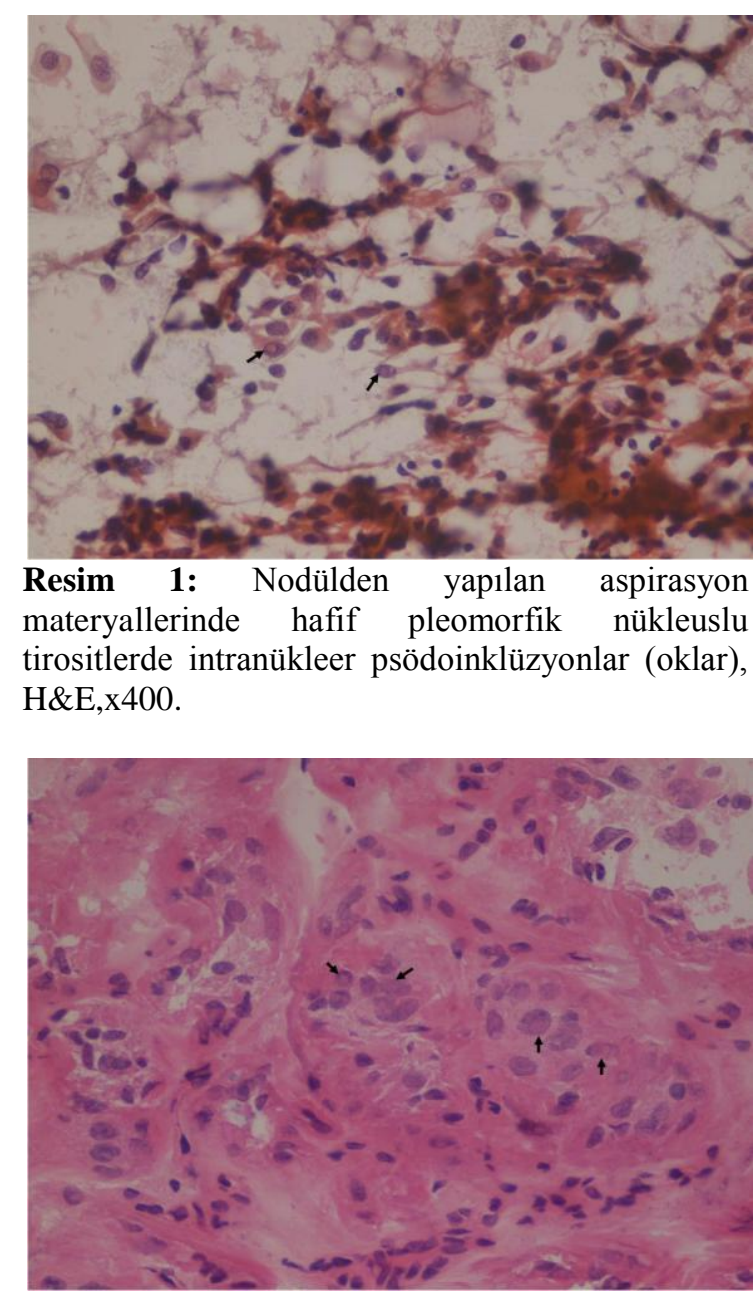

Resim 2: Frozen kesitlerde nükleuslarda psödoinklüzyonlar (oklar), H\&E,x400. 


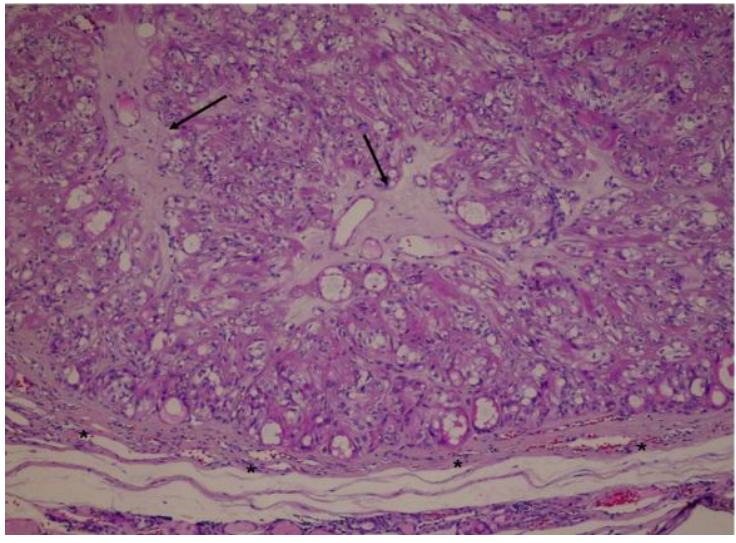

Resim 3: Parafin kesitlerde normal tiroid dokusundan ince fibröz kapsülle (yıldızlar) ayrılmış, hyalinize stromada (oklar) trabeküler yapılar oluşturmuş hücrelerden meydana gelen adenom, $H \& E, x 200$.

\section{Tartışma}

HTA tiroidin nadir görülen bir tümörüdür ve genellikle orta yaşlı kadınlarda görülür (2). HTA sitolojisi papiller karsinoma benzer. Hipersellülarite, nükleer yarıklanma, nükleer psödoinklüzyon ve toz şeklinde kromatin varlığı gibi özelliklere sahiptir. Folliküler neoplazm olarak şüphelenilmesine sebep olan mikrofolliküler değişiklikler, medüller karsinom olarak şüphelenilmesine sebep olan amiloid benzeri hyalinize materyal HTA'da görülebilir (2,3). Ancak papiller yapılar hyalinize trabeküler adenom sitolojisinde görülmez (4). Bizim olgumuzda nodülün sitolojisi kolloidden ve hücreden fakirdi. Tirositlerde yaygın intranükleer inklüzyonlar, fokal alanlarda nükleer yarıklanma görüldü.

HTA makroskopik olarak genellikle komşu tiroid dokusundan ayrılan kapsüllü nodül şeklinde görülür. Mikroskopik olarak da hücreler belirgin trabeküler yapılar oluşturur ve stromal hyalinizasyon ile fibrozis görülür. Genellikle kapsül ve damar invazyonu görülmez (2,5). Bizim olgumuzda da iyi sinırlı ince fibröz kapsülle çevrili hyalinize stromaya sahip uniform nukleuslu hücrelerden oluşan trabeküler yapılar yapmış tümör izlenmiştir.

HTA papiller ve medüller karsinomla karışması nedeniyle histolojik olarak ayırımı için ilave ek yöntemlere ihtiyaç duyulmaktadır. Kalsitonin negatifliği ile medüller karsinomdan ayrılmaktadır. Medüller karsinomda Kongo red ve diğer amiloid belirleyicileri pozitiftir (2).
HTA'da nükleer psödoinklüzyon, yarıklanma ve bazen psammom cisimciği olması sebebiyle papiller karsinomdan ayırmak çok güçtür. Hyalinize trabeküler adenom tiroglobulin ve TTF-1 pozitiftir. Bazı otörler MIB-1 ile sitoplazmik ve membranöz boyanmanın HTA'ya özgü bir bulgu olduğunu bildirmişlerdir. $\mathrm{Bu}$ boyanma paterni diğer tiroid neoplazmlarında görülmez. HTA'da kromogranin ve sinaptofizin gibi nöroendokrin belirleyicileri pozitiftir. Bunun yanısıra CK19, ve galaktin-3 pozitiftir. HBME-1 negatiftir (69). Bizim olgumuzda tümör hücreleri tiroglobulin ile pozitif olup, CK19, kalsitonin ve HBME ile negatifti. Kristal viyole ile yapılan histokimyasal boyamalarda boyanma görülmedi.

HTA'da papiller karsinomdaki gibi RET/PTC mutasyonu saptanmaktadır. Yapilan bir çalışmada 28 HTA'nın \%47 gibi yüksek bir kısmında RET/PTC mutasyonu saptanmıştır. Aynı çalışmada HTA olgularında B-raf ve Nras mutasyonu saptanmamıştır. Ancak papiller karsinomlu olgularda da N-ras mutasyonu tespit edilmemiştir. B-raf mutasyonu papiller karsinomlu olguların \%40'inda saptanmıştır. $\mathrm{Bu}$ nedenle B-raf mutasyonunun papiller tiroid karsinomu ve HTA'yı ayırmada önemli olduğu ileri sürülmüştür (9).

Hyalinize trabaküler adenom genellikle benign karakterde olmakla birlikte nadir olarak malign klinik gidiş gösterebilir. Malign olmasına kapsüler, vasküler ve lenf nodu metastazı ile karar verilir ve hyalinize trabeküler karsinom olarak adlandırılır. Mc Cluggage ve ark. 2 olguda kapsüler invazyon ve venöz invazyon varlığını göstermişlerdir (5). Olgumuzun incelenen seri kesitlerinde kapsül invazyonu ve venöz invazyon görülmemiştir.

Sonuç olarak HTA tiroidin folliküler adenomlarına benzer klinik ve morfolojik özelliklere sahiptir. Ancak sitolojide ve frozen kesitlerde papiller karsinom ile karışabilir. Sitolojide papiller yapıların görülmemesi, frozen kesitlerde ise hyalinize stroma ve trabeküler hücresel dizilim yol gösterici olabilir. Ancak kesin tanı parafin kesitlerle verilebilir.

Çıkar Çatışması: Yoktur 


\section{Kaynaklar}

1. Carney JA, Ryan J, Goellner JR. Hyalinizing trabecular adenoma of the thyroid gland. Am J Surg Pathol 1987;11:583-91

2. Evenson A, Mowschenson $\mathrm{P}$, Wang $\mathrm{H}$, et al. Hyalinizing trabecular adenoma-an uncommon thyroid tumor frequently misdiagnosed as papillary or medullary thyroid carcinoma. The Am J Surg 2007;193:707-12

3. Casey MB, Sebo TJ, Carney JA. Hyalinizing trabecular adenoma of the thyroid gland. Am J Clin Pahol 2004;122:506-10

4. Bishop JA, Ali SZ. Hyalinizing Trabecular adenoma of the thyroid gland. Diagnostic Cytopathology 2010;39:306-10

5. McCluggage WG, Sloan JM. Hyalinizing trabecular carcinoma of the thyroid gland. Histopathology 1996;28:357-62
6. Galgano MT, Mills SE, Stelow EB. Hyalinizing trabecular adenoma of the thyroid revisited: A histologic and immunohistochemical study of thyroid lesions with prominent trabecular architecture and sclerosis. Am J Surg Pathol 2006; 30:1269-73

7. Papotti M, Riella P, Montemurro F, Pietribiasi F, Bussolati G. Immunophenotypic heterogeity of hyalinizing trabecular tumors of the thyroid. Histopathology 1997;31:525-33

8. Ohtsuki $\mathrm{Y}$, Kimura $\mathrm{M}$, Murao $\mathrm{S}$, et al. Immunohistochemical and electron microscopy studies of a case of hyalinizing mass associated with it. Med Mol Morphol 2009;42:189-94

9. Salvatore G, Chiappetta G, Nikiforov YE, et al. Molecular profile of hyalinizing trabecular tumours of the thyroid: High prevalence of RET/PTC rearrangements and absence of B-raf and N-ras poit mutations. Eur J Cancer 2005;41:816-21 